\title{
In ovo Administration of Nucleosides Improved the Performance, Apparent Metabolizable Energy and Gut Development in Broiler Chickens
}

\section{OPEN ACCESS}

Edited by:

Demin Cai,

Yangzhou University, China

Reviewed by:

Alireza Seidavi,

Islamic Azad University, Rasht

Branch, Iran

Rihua Cong,

Northwest $A$ and $F$ University, China

*Correspondence:

Marappan Gopi

getgopi72@gmail.com

tThese authors have contributed equally to this work

₹Present address:

Marappan Gopi,

Animal Nutrition Division, National Institute of Animal Nutrition and Physiology, Karnataka, India

Specialty section:

This article was submitted to Animal Nutrition and Metabolism,

a section of the journal

Frontiers in Veterinary Science

Received: 15 July 2020 Accepted: 05 November 2020 Published: 11 December 2020

Citation:

Gopi M, Manojkumar V, Verma AK, Singh P, Rokade JJ, Pearlin BV, Monika M, Madhupriya $V$,

SaravanaKumar $M$ and Tamilmani T (2020) In ovo Administration of

Nucleosides Improved the

Performance, Apparent Metabolizable

Energy and Gut Development in Broiler Chickens.

Front. Vet. Sci. 7:583748. doi: 10.3389/fvets.2020.583748

\begin{abstract}
Marappan Gopi ${ }^{1 \times \neq \neq}$, Villavan Manojkumar ${ }^{2+}$, Ashok Kumar Verma ${ }^{2}$, Putan Singh ${ }^{2}$, Jaydip Jaywant Rokade ${ }^{1}$, Beulah V. Pearlin ${ }^{1}$, Madheswaran Monika',

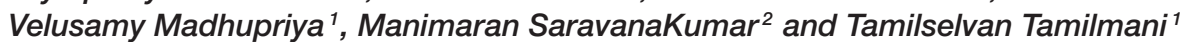

${ }^{1}$ Division of Avian Physiology and Reproduction, Central Avian Research Institute, Uttar Pradesh, India, ${ }^{2}$ Division of Animal Nutrition, Indian Veterinary Research Institute, Uttar Pradesh, India

An in ovo study on the effect of the administration of a combination of nucleosides (25, 50 , and $100 \mathrm{mg} / \mathrm{egg}$ ) on hatchability, growth performance, energy metabolizability, and intestinal morphology in broilers was carried out. Four hundred eighty (480) fertile eggs were divided into four groups (in four replicates each having 30 eggs). On the 18th days of incubation of the eggs, candling was carried out and the fertile eggs were selected and given one of the four in ovo administrations. Group one served as control and was injected with phosphate-buffered saline (PBS). The other groups were given in ovo administration of nucleosides $(25,50$, and $100 \mathrm{mg} / \mathrm{egg})$ at $100 \mu \mathrm{l}$ through the yolk sac route, and chicks of respective groups were hatched out. Among the experimental groups, the hatchability was comparable; however, the hatchability was affected in the group injected with a higher level of nucleosides at $100 \mathrm{mg} / \mathrm{egg}$. The hatched out chicks from higher doses of nucleosides (50 and $100 \mathrm{mg}$ ) had higher body weight $(\mathrm{BW})(P<0.05)$ than the control. Higher energy metabolizability (\%) was observed in nucleoside-injected groups. Plasma protein concentration was higher in groups administered with nucleosides (50 and $100 \mathrm{mg}$ ). Histologically, the intestinal villi length was maximum in $100 \mathrm{mg}$-injected group followed by 50 and $25 \mathrm{mg}$. Relative expression of homeobox (Cdx) in the jejunum was significantly $(P<0.05)$ upregulated in all the injected groups at 3,7 , and 14 days of age. Nucleoside-administered groups had better performance, energy metabolizability, and intestinal morphology. Among the experimental groups, the administration of nucleosides at $50 \mathrm{mg} / \mathrm{egg}$ resulted in higher growth performance, plasma protein, intestinal surface, and villi development in broiler chickens.

Keywords: nucleosides, in ovo, gut development, performance, broiler

\section{INTRODUCTION}

Genetic improvement paved the way for heavier birds with improved feed utilization efficiency under reduced rearing periods. As the productivity of birds increases, the demand of embryos for nutrients does changes. Early functions of the digestive tract are vital for chicken's growth and optimum muscle development. The small intestine undergoes both morphological and molecular changes during incubation. These changes are essential for the birds to adapt to rapid transition 
from yolk to physical nutrient sources. The changes were quite evident as the weight of the intestine reaches about $3.5 \%$ of embryonic weight at hatch from $1 \%$ at 17 days of incubation (1). From the 19th day, the yolk sac's internalization into the body cavity takes place and serves as source of energy following hatching until the exposure to feed (2-4).

In broilers of 35 days growing period, $37 \%$ of their life span is spent in incubation (21 days) at hatchery (5). Any interventions during incubation that promotes/accelerates growth would have a significant impact on post-hatch performance. The use of in ovo technique (administration of nutrients or vaccines) had resulted in beneficial effects during their posthatch performance. Moreover, this prenatal feeding triggers the intestinal development by enhancing villi development and intestinal capacity to digest and absorb nutrients and provides a basis for muscle growth (6-8). Similarly, the in ovo administration of nanoparticles of calcium carbonate accelerated the bone development in broilers (9). For in ovo injection, with more area, the yolk sac route is an ideal site for administration (5). A recent study indicated that the use of prebiotic (galactooligosaccharides) through in ovo route mitigated the negative effects of heat stress in broiler chickens (10). It is quite evident that any interventions during embryonic stage has a positive effect of post-hatch performance in broiler chickens.

Nucleotides (low molecular weight compound) are the materials for nucleic acids. Nucleotides consist of a pentose sugar, nitrogenous base, and phosphate group, whereas nucleosides consist of all the above except phosphate group (11). Nucleotides play critical roles in many biological processes in the body. Rapidly proliferating tissues such as immune system and intestinal mucosal cells during stress and early growth periods require more amount of nucleotides which cannot be supplied merely by de novo synthesis. The salvage pathway, which harvests nucleobases from blood and diet, could support their demands (12). Nucleotides are involved in gastrointestinal tract and skeletal muscle development, and immune response (13).

The in ovo supplementation of nucleotides will play an important role in developing various systems, especially the gastrointestinal and immune systems. During the embryonic stage, the intestinal mucosal barrier and enzyme system is immature and hence the administered quantity will enter into the bird's body without any loss $(14,15)$. Since nucleotides are converted to nucleosides after absorption, this study was undertaken to assess the their effect following in ovo administration at different dosages on growth performance, energy metabolizability, plasma total protein, uric acid, villi length, and expression of gut development genes.

\section{MATERIALS AND METHODS Ethical Approval}

All experimental procedures involved in the study, such as the rearing of experimental birds and sampling, were approved by the institute animal ethics committee and members of CPCSEA nominees. The IAEC approval number is CARI/CPCSEA/2017/07.

\section{Birds and Sampling}

A total of 480 fertile eggs of white commercial broiler chicken (CARIBRO Vishal) were incubated in an incubator. All the eggs were incubated at normal incubation temperature $\left(99.5^{\circ} \mathrm{F}-99.75^{\circ} \mathrm{F}\right)$ and relative humidity $(50-60 \%)$ for initial 17 days. After 17 days of incubation, the eggs were divided into four treatments, each consisting of 120 eggs for in ovo injection. Each group was consisted of four replicates having 30 eggs in each. On the 18th day, the eggs were candled, and the fertile eggs were reweighed and transferred to the laminar airflow for in ovo administration of nucleosides. Out of the four groups, eggs in the first group served as control which was injected with phosphatebuffered saline (PBS). The other three were treatment groups and were given in ovo administration of nucleosides $(25,50$, and $100 \mathrm{mg} / \mathrm{egg}$ ) at the rate of $100 \mu \mathrm{l}$ through the chorioallantoic membrane using tuberculin needles and deposited into the yolk sac as per the protocol of Bhanja et al. (16). The doses were based on our earlier in vivo experiments (17). Commercial nucleosides (adenosine, guanosine, cytosine, and uridine-100\% purity) were used in the study (HiMedia India Pvt. Ltd., Mumbai, India), mixed in equal proportion, and suspended in autoclaved PBS. Immediately after injection, the site was sealed with sterile paraffin. All the eggs were transferred to a hatcher, and the chicks were hatched out.

\section{Hatchability Percentage and Experiment Diets}

The hatchability percentage was calculated on fertile egg basis, and break out analyses was performed to study the causes for embryonic mortality. Following hatching, the chicks from respective groups were pulled out, wing banded, weighed, and grouped into respective groups and labeled. The hatched out chicks of respective groups (five replicates) were reared with common broiler feed for 42 days. The birds were fed with prestarter (1-14 days), starter (15-28 days), and finisher (29-42 days) diets as per the nutritional recommendations of the Indian Council of Agricultural Research (18). The physical and chemical composition of the experimental diet is presented in Table 1.

\section{Energy Metabolizability and Production Performance}

A metabolism trial was conducted after 14 days of age, with 4 days of collection period and energy metabolizability was studied. The birds were kept individually in metabolic cages. The feed was offered to the birds in the cages in a separate feeder. Simultaneously, the residue was collected next day. The excreta were collected daily at the morning (10 a.m.), weighed, and stored appropriately for further analyses. Samples of experimental diets together with droppings were chemically analyzed for gross energy (GE) estimation using an adiabatic bomb calorimeter. The apparent metabolizable energy (AME) was determined by utilizing the balance data and the GE content of diets and droppings (19). The replicate feed consumption at different phases (14th, 28th, and 42nd day of age) and body weight (BW) 
TABLE 1 | Feed ingredients and chemical composition of experimental diet (as-fed basis).

\begin{tabular}{|c|c|c|c|}
\hline Ingredients (\%) & Pre-starter & Starter & Finisher \\
\hline Corn & 546.0 & 542.0 & 576.2 \\
\hline Soybean meal (48\% CP) & 395.8 & 378.0 & 325.8 \\
\hline Rice bran oil & 21.20 & 42.40 & 58.60 \\
\hline Calcite & 15.40 & 15.20 & 17.30 \\
\hline Di-calcium phosphate & 9.00 & 9.50 & 11.00 \\
\hline Salt & 1.80 & 1.80 & 1.80 \\
\hline L-Lysine & 3.00 & 1.50 & 1.70 \\
\hline DL-Methionine & 3.00 & 2.80 & 2.70 \\
\hline Phytase & 0.15 & 0.15 & 0.15 \\
\hline Mineral premix ${ }^{a}$ & 0.15 & 0.15 & 0.15 \\
\hline Vitamin premix ${ }^{b}$ & 0.14 & 0.14 & 0.14 \\
\hline Coccidiostat $^{c}$ & 0.10 & 0.10 & 0.10 \\
\hline Toxin binder ${ }^{d}$ & 0.50 & 0.50 & 0.50 \\
\hline \multicolumn{4}{|l|}{ ANALYZED VALUES } \\
\hline Crude protein & 226.5 & 216.5 & 197.0 \\
\hline Metabolizable energy (MJ/kg) & 12.55 & 13.08 & 13.60 \\
\hline Calcium & 9.60 & 9.50 & 9.00 \\
\hline Available phosphorus* & 4.50 & 4.60 & 4.60 \\
\hline Lysine* & 14.20 & 12.50 & 11.40 \\
\hline Methionine* & 6.20 & 5.90 & 5.50 \\
\hline
\end{tabular}

${ }^{*}$ Calculated values.

a Mineral premix composition: 91 mg manganese, $91 \mathrm{mg}$ zinc, $85 \mathrm{mg}$ iron, $1.82 \mathrm{mg}$ iodine, $30.24 \mathrm{mg}$ copper, and $0.365 \mathrm{mg}$ cobalt/ $\mathrm{kg}$.

bitamin premix composition: 16,500 IU retinol, 3,200 IU cholecalciferol, $2 \mathrm{mg}$ menadione, $5 \mathrm{mg}$ thiamine, $13 \mathrm{mg}$ riboflavin, $8 \mathrm{mg}$ pyridoxine, $320 \mathrm{mg}$ niacin, $0.05 \mathrm{mg}$

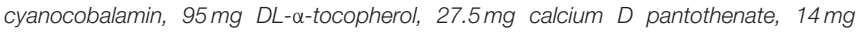
folic acid/kg.

${ }^{c}$ Coccidiostat supplied $125 \mathrm{mg}$ Dinitro-ortho-toluamide/kg.

'Toxin binder composition: blend of organic acids, hydrated sodium calcium aluminum silicate, mannan oligosaccharides, and oxine copper (Check-O-Tox, Zoetis, India).

at similar stages were recorded.

$$
\operatorname{AME}(\mathrm{kcal} / \mathrm{kg})=\frac{\left(\mathrm{FC} \times \mathrm{GE}_{\mathrm{f}}\right)-\left(\mathrm{E}_{\mathrm{w}} \times \mathrm{GE}_{\mathrm{e}}\right)}{\mathrm{FC}}
$$

Where,

FC, feed consumption (g/bird/day)

$E_{\mathrm{W}}$, dried excreta weight (g/bird/day)

$\mathrm{GE}_{\mathrm{f}}$, gross energy of feed $(\mathrm{kcal} / \mathrm{kg})$

$\mathrm{GE}_{\mathrm{e}}$, gross energy of excreta $(\mathrm{kcal} / \mathrm{kg})$.

\section{Plasma Total Protein and Uric Acid Content}

On $0,3,7,14,21$, and 42 days of age, 10 birds (one male and one female per replicate) from each group were sacrificed in the morning before feeding, and blood samples were collected from the jugular vein in anticoagulant-coated tubes. The tubes were centrifuged at 2,500 rpm for $20 \mathrm{~min}$ to separate the plasma, and it was stored at $-20^{\circ} \mathrm{C}$ until analysis. Plasma total protein and uric acid contents were quantified using Coral Clinical Systems, Tulip Diagnostics (P) Ltd., Goa. Plasma total protein and uric acid concentration were estimated by biuret and Uricase/PAP method, respectively.
TABLE 2 | Oligonucleotide sequences for Cdx gene expression studies.

\begin{tabular}{llcc}
\hline Gene & Primer sequence & $\begin{array}{c}\text { Annealing } \\
\text { temperature }\end{array}$ & Accession no. \\
\hline Cdx & F-CTCGGACTTCGCCAGCTACC & $56.0^{\circ} \mathrm{C}$ & AB046532 \\
& R-TGCGCCTCATCCATTCGTAC & & \multirow{2}{*}{ K01458 } \\
GAPDH & F-GTGTGCCAACCCCCAATGTCTCT & $58.2^{\circ} \mathrm{C}$ & \\
& R-GCAGCAGCCTTCACTACCCTCT & & \\
\hline
\end{tabular}

\section{Intestinal Gross and Histomorphology}

Ten birds from each group were randomly selected and sacrificed (days 0,7 , and 14) by cervical dislocation and the whole intestinal segment was removed from the birds. Both the weight and length were measured and expressed in percent BW and centimeter per kilogram BW, respectively. The midpoint from the pancreatic loop to the Meckel's diverticulum about $1 \mathrm{~cm}$ of the jejunum part was excised, flushed with normal saline to remove the contents, and fixed in 10\% neutral-buffered formal saline for histological analysis. For each sample, both longitudinal and cross sectional segments were made and analyzed under light microscope. Intestinal villi length was measured from tip of the villi to the villus-crypt junction using Zeiss microscope blue core software, and for each sample, six measurements were recorded.

\section{Relative Expression of Intestinal Development Gene (Cdx)}

The relative expression and quantification of $\mathrm{Cdx}$ gene in the jejunum was quantified by real-time PCR. The jejunum samples ( $N=40 ; 10$ per treatment) were collected in RNAlater at 3,7 , and 14 days of age and stored at $-20^{\circ} \mathrm{C}$ until further processing. The total RNA was isolated from the jejunum by TRIzol (Invitrogen, USA) extraction method. The quality of isolated RNAs was assessed by the absorbance ratio at 260$280 \mathrm{~nm}$ using a microvolume spectrophotometer (NanoDrop ${ }^{\circledR}$, Thermo Scientific Fischer, USA). The RNAs having a ratio value of 1.8-2 were taken for further processing. The first strand cDNA were synthesized using RevertAid cDNA Synthesis Kit (MBI Fermentas, USA). PCR and qPCR were carried out in thermal cycler and real-time cycler (Bio-Rad Laboratories, USA) using standard conditions. All the samples were run in triplicate with non-template control (NTC) included in each PCR reaction to check DNA contamination. Oligo-nucleotide sequence of gene primers forward and reverse are provided in Table 2. GAPDH was used as a reference gene.

\section{Statistical Analysis}

Data collected on various parameters were subjected to analysis of variance using Statistical Package for Social Sciences version 16.0. The observations on hatchability, body weight, and feed intake were subjected to single-factor analysis. The observations on plasma total protein, plasma uric acid, gross intestinal morphology, and jejunal villi length were subjected to two-factor analysis to interpret the effect of treatment, duration, and its interaction. The means were compared for significance using Tukey's range test. 
TABLE 3 | Effect of in ovo nucleoside administration on the hatchability (\%) and embryonic mortality (\%) in broiler chickens.

\begin{tabular}{|c|c|c|c|c|c|c|c|}
\hline \multirow[t]{2}{*}{ Group } & \multicolumn{2}{|c|}{ Egg weight (g) } & \multirow[t]{2}{*}{ Hatchability (\%) } & \multicolumn{4}{|c|}{ Embryonic mortality (\%) } \\
\hline & Day 1 & Day 18 & & Dead in shell & Infected & Dead after injection & Live pipping \\
\hline Control & 60.78 & 52.35 & 75.97 & 12.00 & 3.00 & 7.92 & 1.11 \\
\hline $25 \mathrm{mg}$ & 60.20 & 53.48 & 78.55 & 10.89 & 3.22 & 7.34 & 0.00 \\
\hline $50 \mathrm{mg}$ & 59.46 & 53.43 & 78.33 & 11.54 & 3.45 & 8.23 & 1.51 \\
\hline $100 \mathrm{mg}$ & 59.56 & 53.48 & 74.76 & 8.78 & 3.33 & 10.69 & 2.44 \\
\hline
\end{tabular}

TABLE 4 | Effect of in ovo nucleoside administration on the feed consumption ( $\mathrm{g} / \mathrm{bird}$ ) and energy metabolizability (\%) in broiler chickens.

\begin{tabular}{lccccc}
\hline Group & 2nd week & 4th week & 6th week & Overall & $\begin{array}{c}\text { Energy } \\
\text { metabolizability (\%) }\end{array}$ \\
\hline Control & 539 & $1,038^{\mathrm{c}}$ & 2,053 & 3,630 & $77.13^{\mathrm{b}}$ \\
$25 \mathrm{mg}$ & 537 & $1,093^{\mathrm{b}}$ & 2,026 & 3,656 & $83.79^{\mathrm{a}}$ \\
$50 \mathrm{mg}$ & 557 & $1,096^{\mathrm{b}}$ & 2,037 & 3,690 & $86.65^{\mathrm{a}}$ \\
$100 \mathrm{mg}$ & 573 & $1,143^{\mathrm{a}}$ & 2,101 & 3,717 & $84.46^{\mathrm{a}}$ \\
SEM & 1.24 & 4.70 & 10.88 & 16.87 & 0.02 \\
$P$-value & 0.241 & 0.031 & 0.094 & 0.134 & 0.001
\end{tabular}

Means within column bearing different superscripts differ significantly $(P<0.05)$.

\section{RESULTS}

\section{Hatchability}

The effect of in ovo nucleoside administration on egg weight during incubation, the percentage of hatchability, and embryonic mortality is presented in Table 3 . There was a reduction in egg weight during incubation on the 18th day compared to day 0 . The hatchability was comparable among the injected groups; however, the hatchability was affected in groups injected with a higher level of nucleosides at $100 \mathrm{mg} / \mathrm{egg}$. The unhatched eggs were broken out, and the cause of embryonic mortality was found out. The results of egg break analysis of unhatched eggs did not show any group-specific lesions, and the pattern of mortalities were uniform among the groups.

\section{Energy Metabolizability and Production Performance}

No significant difference among the groups was observed at fortnight and overall feed intake, except during the fourth week of experiment (Table 4). At the fourth week, the birds under higher administered dose $(100 \mathrm{mg})$ had consumed more $(P<$ $0.05)$ feed than the other three groups. The birds hatched out from the groups that are injected with higher levels of nucleosides $(50$ and $100 \mathrm{mg})$ had higher BW $(P<0.05)$ than the control (Table 5). The birds injected with lower dose $(25 \mathrm{mg})$ exhibited intermediate response. The energy metabolizability (\%) among the different groups showed a significant $(P<0.01)$ difference at 14 days of age (Table 6). Higher energy metabolizability (\%) was observed in the in ovo-injected birds $(25,50$, and $100 \mathrm{mg})$ when compared to the control group $(83.79 \%, 86.65 \%$, and 84.46 vs. $77.13 \%)$.
TABLE 5 | Effect of in ovo nucleoside administration on the body weight (g) in broiler chickens.

\begin{tabular}{lcccc}
\hline Group & Hatch weight & 2nd week & 4th week & 6th week \\
\hline Control & 46.2 & $449.1^{\mathrm{b}}$ & $1,091.7^{\mathrm{b}}$ & $2,026.3^{\mathrm{b}}$ \\
$25 \mathrm{mg}$ & 46.3 & $447.1^{\mathrm{b}}$ & $1,134.8^{\mathrm{ab}}$ & $2,072.9^{\mathrm{ab}}$ \\
$50 \mathrm{mg}$ & 46.9 & $463.8^{\mathrm{a}}$ & $1,188.5^{\mathrm{a}}$ & $2,123.5^{\mathrm{a}}$ \\
$100 \mathrm{mg}$ & 48.41 & $477.6^{\mathrm{a}}$ & $1,189.9^{\mathrm{a}}$ & $2,162.4^{\mathrm{a}}$ \\
SEM & 0.36 & 3.25 & 12.19 & 14.03 \\
P-value & 0.232 & 0.036 & 0.043 & 0.031 \\
\hline
\end{tabular}

Means within column bearing different superscripts differ significantly $(P<0.05)$.

\section{Plasma Total Protein and Uric Acid}

The plasma concentration of total protein showed significant difference $(P<0.05)$ due to treatment, period, and its interaction (Table 6). The results revealed higher protein concentration in groups administered with higher nucleosides (50 and $100 \mathrm{mg}$ ) when compared to the control group. Similarly, the protein content showed age-dependent linearity and reached a higher concentration at 42 days of age. The interaction effect revealed a lower protein concentration at initial stages (days 0 and 3 ), and then, the values showed a steady increase with higher levels in supplemented groups than the control. The result for the concentration of plasma uric acid $(\mathrm{mg} / \mathrm{dl})$ is furnished in Table 7. Group mean showed no significant difference $(P>0.05)$, while the period mean exhibited a significant $(P<0.05)$ reduction in their concentration as the age increases. The interaction did not reveal any treatment $\times$ period association in the levels of serum uric acid.

\section{Intestinal Morphology and Development}

The intestinal length and weight were comparable $(P>0.05)$ among the groups, but their weight showed period mean significant difference $(P<0.01)$ (Table 8). The results showed that intestinal length at days 0 and 7 differed significantly $(P<$ 0.01 ) from day 14 and intestinal weight at day 0 significantly differed $(P<0.01)$ from other periods. Reduction in the intestinal length has been observed on day 14 when compared to other periods. Among all periods, day 7 had the highest intestinal length and weight. The least length and weight were noticed on day 14 and day 0 , respectively. Interaction study of intestinal morphology revealed that the control group had higher intestinal length and weight. The least intestinal length 
TABLE 6 | Effect of in ovo nucleoside administration on the plasma total protein ( $\mathrm{g} / \mathrm{dl})$ concentration in broiler chickens.

\begin{tabular}{|c|c|c|c|c|c|c|c|c|c|c|c|}
\hline \multirow[t]{2}{*}{ Group } & \multicolumn{6}{|c|}{ Period (days) } & \multirow[t]{2}{*}{ Group mean } & \multicolumn{3}{|c|}{$P$-value } & \multirow[t]{2}{*}{ SEM } \\
\hline & 0 & 3 & 7 & 14 & 21 & 42 & & G & $P$ & $G \times P$ & \\
\hline Control & $3.36^{h}$ & $3.66^{g h}$ & $5.14^{e}$ & $5.90^{\mathrm{b}}$ & $5.72^{\mathrm{C}}$ & $5.18^{e}$ & $4.83^{z}$ & 0.033 & 0.001 & 0.016 & 0.17 \\
\hline $25 \mathrm{mg}$ & $4.02^{f g}$ & $4.30^{f}$ & $5.86^{b c}$ & $5.30^{\text {de }}$ & $6.02^{b}$ & $6.35^{a}$ & $5.14^{x y}$ & & & & \\
\hline $50 \mathrm{mg}$ & $3.55^{\mathrm{gh}}$ & $4.49^{f}$ & $5.74^{c}$ & $5.75^{c}$ & $6.11^{a b}$ & $6.43^{a}$ & $5.35^{x}$ & & & & \\
\hline $100 \mathrm{mg}$ & $3.74^{g h}$ & $4.28^{f}$ & $5.47^{d}$ & $5.39^{d}$ & $6.14^{\mathrm{ab}}$ & $6.64^{a}$ & $5.28^{x}$ & & & & \\
\hline Period mean & $3.67^{\mathrm{C}}$ & $4.18^{C}$ & $5.55^{\mathrm{AB}}$ & $5.59^{\mathrm{AB}}$ & $6.00^{\mathrm{A}}$ & $6.15^{\mathrm{A}}$ & & & & & \\
\hline
\end{tabular}

Means bearing different superscript within column $(x-z)$, row $(A-C)$, and interaction $(a-h)$ differ significantly $(P<0.05)$.

$G \times P$, group $\times$ period interaction .

TABLE 7 | Effect of in ovo nucleoside administration on the plasma uric acid (mg/dl) content in broiler chickens.

\begin{tabular}{|c|c|c|c|c|c|c|c|c|c|c|c|}
\hline \multirow[t]{2}{*}{ Group } & \multicolumn{6}{|c|}{ Period (days) } & \multirow[t]{2}{*}{ Group mean } & \multicolumn{3}{|c|}{$P$-value } & \multirow[t]{2}{*}{ SEM } \\
\hline & 0 & 3 & 7 & 14 & 21 & 42 & & G & $P$ & $G \times P$ & \\
\hline Control & 5.89 & 5.59 & 5.44 & 5.32 & 5.41 & 5.17 & 5.47 & 0.511 & 0.001 & 0.316 & 0.325 \\
\hline $25 \mathrm{mg}$ & 6.07 & 5.95 & 5.56 & 5.46 & 5.39 & 5.29 & 5.62 & & & & \\
\hline $50 \mathrm{mg}$ & 6.18 & 5.98 & 5.68 & 5.48 & 5.23 & 5.16 & 5.62 & & & & \\
\hline $100 \mathrm{mg}$ & 6.22 & 6.02 & 5.76 & 5.55 & 5.47 & 5.24 & 5.71 & & & & \\
\hline Period mean & $6.09^{A}$ & $5.89^{A}$ & $5.61^{\mathrm{B}}$ & $5.45^{\mathrm{BC}}$ & $5.38^{\mathrm{BC}}$ & $5.22^{C}$ & & & & & \\
\hline
\end{tabular}

Means bearing different superscript differ significantly $(P<0.01)$.

$G \times P$, group $\times$ period interaction.

TABLE 8 | Effect of in ovo nucleoside administration on the intestinal gross morphology in broiler chickens.

\begin{tabular}{|c|c|c|c|c|c|c|c|c|}
\hline \multirow[t]{2}{*}{ Group } & \multicolumn{3}{|c|}{ Period (days) } & \multirow[t]{2}{*}{ Group mean } & \multicolumn{3}{|c|}{$P$ value } & \multirow[t]{2}{*}{ SEM } \\
\hline & 0 & 7 & 14 & & G & $\boldsymbol{P}$ & $G \times P$ & \\
\hline \multicolumn{9}{|c|}{ Intestinal length (cm/kg body weight) } \\
\hline Control & $815.56^{a b c}$ & $910.47^{a}$ & $529.92^{\mathrm{bcd}}$ & 751.98 & 0.446 & 0.001 & 0.005 & 28.991 \\
\hline $25 \mathrm{mg}$ & $902.55^{\mathrm{a}}$ & $963.75^{a}$ & $488.27^{\mathrm{cd}}$ & 784.86 & & & & \\
\hline $50 \mathrm{mg}$ & $822.03^{a b c}$ & 789.39abcd & $487.74^{\mathrm{cd}}$ & 699.72 & & & & \\
\hline $100 \mathrm{mg}$ & $808.97^{\mathrm{abcd}}$ & $891.76^{a}$ & $634.77^{\mathrm{abcd}}$ & 778.50 & & & & \\
\hline Period mean & $837.28^{A}$ & $888.84^{A}$ & $535.18^{\mathrm{B}}$ & & & & & \\
\hline \multicolumn{9}{|c|}{ Intestinal weight ( $\%$ body weight) } \\
\hline Control & $38.52^{c}$ & $149.25^{a}$ & $139.01^{a}$ & 108.93 & 0.286 & 0.001 & 0.001 & 7.267 \\
\hline $25 \mathrm{mg}$ & $52.09^{b c}$ & $153.44^{a}$ & $128.39^{a}$ & 111.31 & & & & \\
\hline $50 \mathrm{mg}$ & $39.96^{c}$ & $137.33^{a}$ & $126.89^{a}$ & 101.39 & & & & \\
\hline $100 \mathrm{mg}$ & $34.01^{\mathrm{c}}$ & $133.79^{a}$ & $131.89^{a}$ & 99.90 & & & & \\
\hline Period mean & $41.15^{\mathrm{B}}$ & $143.45^{\mathrm{A}}$ & $131.55^{\mathrm{A}}$ & & & & & \\
\hline
\end{tabular}

Means bearing different superscript within row $(A-B)$ and interaction $(a-d)$ differ significantly $(P<0.01)$.

$G \times P$, group $\times$ period interaction .

was observed in the control group at day 14 and the least weight was observed in the 50-mg group at day 0 . Other groups exhibited an intermediate response. All the groups showed a reduction in intestinal length and weight per unit from day 7-14.

Histomorphological results showed that both group mean and period mean were significantly different $(P<0.01)$. The highest intestinal villi length was observed in the 100 -mg-dose-injected group, followed by 50 and $25 \mathrm{mg}$ (Table 9). The period means exhibited a significant increase in the pattern of villi length up to 42 days. Interaction study revealed that the 100-mg group had the highest villi length on day 42 , and the lowest length was observed in the control group at day 0 . The relative expression of homeobox $(\mathrm{Cdx})$ gene in the jejunum showed significant $(P<$ 0.05 ) upregulation in the injected groups at 3, 7, and 14 days of age (Figure 1). The magnitude of expression is higher during 7 days of age after hatch, whereas the expression is lower at days 3 and 14 . 
TABLE 9 | Effect of in ovo nucleoside administration on the jejunal villi length $(\mu \mathrm{m})$ in broiler chickens.

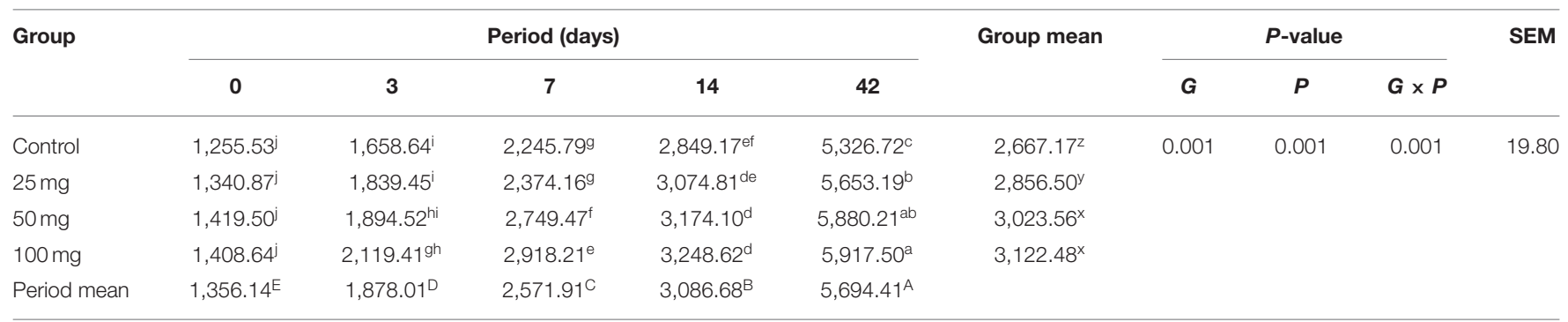

Means bearing different superscript within column $(x-z)$, row $(A-E)$, and interaction $(a-k)$ differ significantly $(P<0.01)$.

$G \times P$, group $\times$ period interaction.

\section{DISCUSSION}

\section{Hatchability (\%)}

The egg weights were comparable among the groups at both during the day of setting and after 18 days of incubation. About $10-12 \%$ of embryonic mortality was encountered after in ovo injection across the injected groups. Among the experimental groups, better hatchability was observed in 25 and 50-mg group. It indicated that the administration of nucleosides had an impact in the hatchability percentage of eggs. The hatchability percentage was negatively related to the concentration of nucleosides. Eggs with lower concentration at $25 \mathrm{mg} / \mathrm{egg}$ showed better hatchability than other eggs which had higher concentration of nucleosides. The hatchability percentage reduction might be due to alteration in the osmolarity inside the egg as the nucleosides were administered as suspension. The nucleosides are sparingly soluble in aqueous solvents, and the administration of nucleosides as a solution instead of suspension would have resulted in better hatchability percentage following in ovo administration. Further studies could be directed toward improving the solubility of these nucleosides by manipulating the $\mathrm{pH}$ of the solvents which could result in better hatchability.

\section{Growth Performance and Energy Metabolizability}

There was a non-significant increase in feed intake of T3 group birds observed in all other three phases (pre-starter, finisher, and overall growth phase). Post-hatch feeding of nucleotides at $0.04,0.05,0.06$, and $0.07 \%$ resulted in significantly higher feed consumption than the control group (20). Hatch weight did not show any significant difference among the groups, which indicated that the administration of nucleosides at the 18th day of incubation did not influence the weight at hatch. Post-hatch bi-weekly BW measurements revealed significant difference $(P<0.05)$ at all the growth phases and overall BW. Supplementation of $0.05 \%$ of commercial nucleotide products (Nucleoforce, containing $26.4 \%$ of balanced total nucleotides) in broiler diets resulted a significant increase in BW from 0 to 21 days of age (21). Similarly, in swine, supplementation of $4.0 \%$ of yeast extract product $\left(\mathrm{NuPro}^{\mathrm{TM}}\right.$ containing $7 \%$ of total nucleic acids) increased the BW (22). Incorporation of $2 \%$ nucleotide and other related compounds (NuPro) increased
BW in broiler chickens when compared to control (23). This increase has been attributed to an increase in the digestibility and absorption of nutrients by the pancreatic and brush border digestive enzymes activity. A similar effect was also observed in the present study. The results further justified our earlier findings, where the dietary supplementation of nucleosides at $0.1 \%$ resulted in significantly higher $\mathrm{BW}$ and gain in broilers. Energy metabolizability results revealed that all the nucleosideinjected groups have higher energy metabolizability than other groups. It indicated that the administration of nucleosides had improved energy metabolizability in broilers. It might be due to the intestine's rapid cell turnover, which increases enzyme activity and energy metabolizability. A study carried out in broilers with supplementation of $2 \%$ nucleotides, NuPro, resulted in higher nutrient digestibility (23).

\section{Plasma Concentration of Total Protein and Uric Acid}

There was an increasing pattern of concentration of total protein, albumin, and globulin observed up to 42 days. These results revealed that nucleoside-injected groups showed a higher protein concentration than the control group in all the periods. Intraperitoneal administration of nucleoside-nucleotide mixture increased total protein concentration in mice (24). This indicates that nucleotides are essential to increase body protein turnover rate, specific protein synthesis, and enterocyte proliferation. Nucleotides facilitate protein formation through messenger RNA synthesis (25). An age-related inverse relation was observed for uric acid due to the degradation of purine bases (26). The administration of nucleosides elevated the concentration of uric acid except at day 42. The higher values in the supplemented groups might be due to higher breakdown of nucleosides, which are then metabolized and excreted as uric acid.

\section{Intestinal Morphology and Development Studies}

Intestinal length and weight per unit weight were reduced $(P$ $<0.01)$ as the bird's age increases from 7 to 14 days. This is due to an increase in the proportion of BW higher than the length and weight of the intestine from day 7-14. An interaction study revealed that up to day 7 , a lower dose-injected group (25 mg) had the highest intestinal length and weight among all groups. Nucleotides appear to stimulate the development of the 

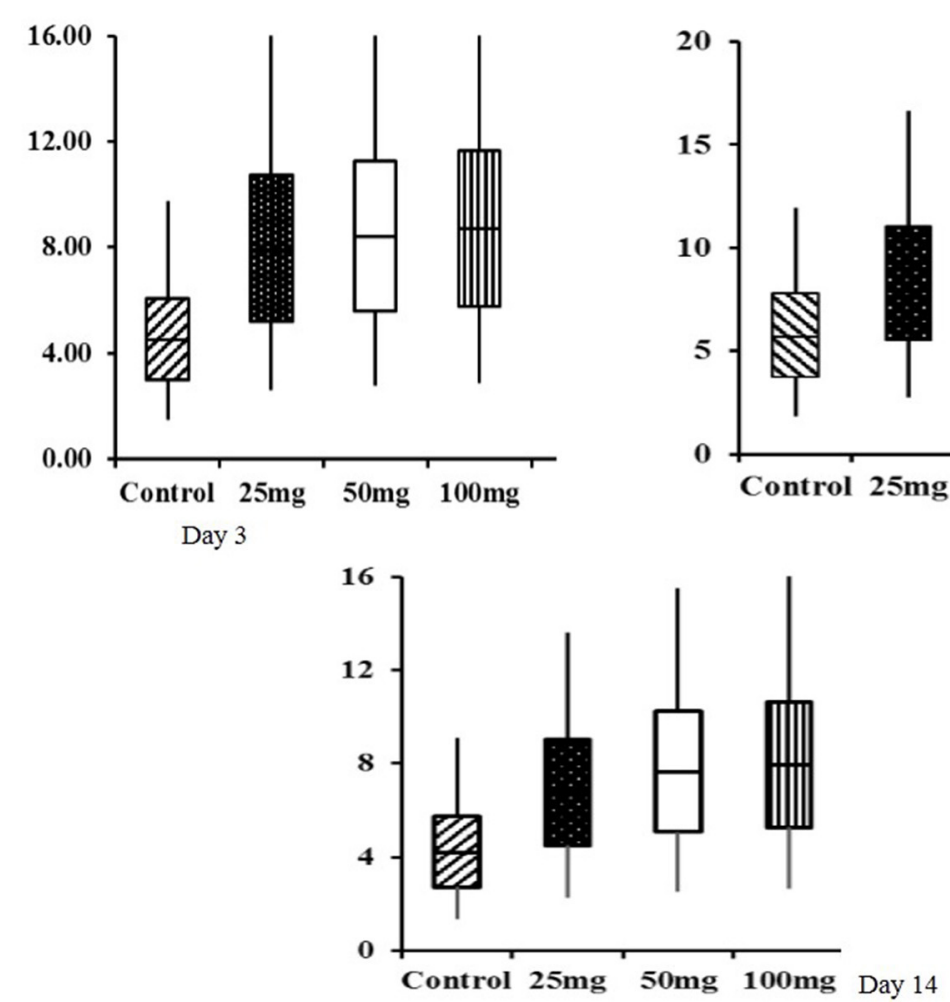

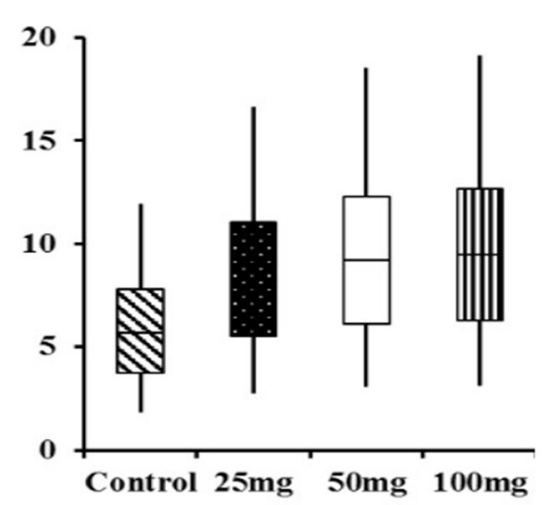

Day 7

FIGURE 1 | Box plot analysis of Cdx gene in jejunum tissue of in ovo injected nucleosides broiler chickens. Box plots, box shows the lower quartile, median (dark line), mean (+ symbol), and upper quartile values and the whisker's show the range of relative expression of Cdx gene in jejunum tissue at 3,7 , and 14 days of age.

intestinal lining and intestinal enzyme concentrations in animals. They also have beneficial effects on recovery from intestinal injuries caused by malnutrition or chronic diarrhea $(27,28)$. This positive effect on the gastrointestinal tract development might be due to enhanced DNA and RNA synthesis because of increased nucleotide pools following intake. This increased DNA and RNA synthesis enhances growth and differentiation of the enterocytes after injuries or malnutrition. Therefore, the administration of nucleosides, which can be converted to nucleotides, may help optimize tissue function in the gastrointestinal tract and stimulate the activity of brush border enzymes. These entire factors may be contributing in increasing intestinal weight.

The intestinal villi length results showed that nucleosideadministered groups were significantly different $(P<0.01)$ from other groups that were non-injected. In all the periods of measurements, the intestinal villi's length was increased in nucleoside-injected groups of broilers. The administration of nucleosides plays an essential role in developing the villi length in the small intestine of broilers. The increased villi length in all nucleoside-administered groups might be due to increased Cdx gene expression, which is the indicator of intestine development. Thus, the mucosal villi's rapid development allows chicks to utilize nutrients more efficiently in their early life and improve growth performance (29). The intestinal epithelium is a rapidly proliferating tissue with a high cell turnover rate, and dietary nucleotides are reported to play a role in the growth and differentiation of the gastrointestinal tract (30). Uauy et al. (27) observed an increased tissue protein, DNA content, as well as the activities of disaccharidase in the intestine of weanling rats fed with $0.8 \% \mathrm{w} / \mathrm{w}$ dietary nucleotide than control. Jung and Batal (23) also reported that birds fed on a diet supplemented with $0.25 \%$ torula yeast RNA and $2 \%$ NuPro, a commercial nucleotide product, had significantly $(P<0.05)$ higher villus heights as compared with the birds fed on the control.

Early weaning in piglets is the most stressful condition which adversely affects the intestine. The consistent occurrence of piglet diarrhea is the most common problem with early weaned piglets. Under this condition, the diet supplemented with $0.1 \%$ or $0.2 \%$ commercial nucleotide-rich yeast extract product (containing $25 \%$ nucleotides) had higher villus heights than the control group $(31,32)$. As nucleosides are the preferred form for absorption by enterocytes, nucleosides were administered in this study. All these effects were due to the administration of nucleosides, which were converted to nucleotides after absorption. Nucleosides also increase the villi length of the small intestine through rapid cell turnover.

The box-plot analysis of $\mathrm{Cdx}$ gene expression revealed upregulation in all the three doses of in ovo injection compared to both the controls. Intraperitoneal administration of nucleoside-nucleotide mixture increased small intestinal RNA levels in mice, which indicated an increased proliferation of enterocytes compared to the control group 
(24). Supplementation of nucleotides provides benefits to enterocyte function during normal periods of growth and development characterized by high demand for DNA and RNA synthesis (33).

\section{CONCLUSION}

From the experiment, it could be concluded that nucleoside administration at the rate of $50 \mathrm{mg} / \mathrm{egg}$ resulted in higher growth performance, intestine surface, and villi development in broiler chickens. Further improvement can be made to overcome the reduction in hatchability percentage by improving the solubility of nucleosides.

\section{DATA AVAILABILITY STATEMENT}

The raw data supporting the conclusions of this article will be made available by the authors, without undue reservation.

\section{ETHICS STATEMENT}

The animal study was reviewed and approved by Chairman, Institute Animal Ethics Committee, CARI. All experimental

\section{REFERENCES}

1. Uni Z, Tako E, Gal-Garber O, Sklan D. Morphological, molecular, and functional changes in the chicken small intestine of the late-term embryo. Poult Sci. (2003) 82:1747-54. doi: 10.1093/ps/82.11.1747

2. Romanoff AL. The Avian Embryo. Structural and Functional development. New York, NY: New York Academic Press (1960)

3. Noble RC, Ogunyemi D. Lipid changes in the residual yolk and liver of the chick immediately after hatching. Biol Neonate. (1989) 56:22836. doi: 10.1159/000243127

4. Noy Y, Sklan D. Yolk and exogenous feed utilization in the posthatch chick. Poult Sci. (2001) 80:1490-5. doi: 10.1093/ps/80.10.1490

5. Kucharska-Gaca J, Kowalska E, Debowska M. In ovo feedingtechnology of the future - A review. Ann Anim Sci. (2017) 17:979-92. doi: 10.1515/aoas-2017-0004

6. Noy Y, Uni Z. Early nutritional strategies. World's Poult Sci J. (2010) 66:63946. doi: 10.1017/S0043933910000620

7. Gholami J, Qotbi AAA, Seidavi AR, Meluzzi A, Tavaniello S, Maiorano G. Effects of in ovo administration of betaine and choline on hatchability results, growth and carcass characteristics and immune response of broiler chickens. Italian J Anim Sci. (2015) 14:187-92. doi: 10.4081/ijas. 2015.3694

8. Roto SM, Kwon YM, Ricke SC. Applications of in ovo technique for the optimal development of the gastrointestinal tract and the potential influence on the establishment of its microbiome in poultry. Front Vet Sci. (2016) 3:63. doi: 10.3389/fvets.2016.00063

9. Salary J, Hemati Matin HR, Ghafari K, Hajati H. Effect of in ovo injection of calcium carbonate nanoparticles on bone post hatched characteristics broiler chicken performance. Iranian J Appl Anim Sci. (2017) 7:663-7.

10. Slawinska A, Zampiga M, Sirri F, Meluzzi A, Bertocchi M, Tavaniello S, et al. Impact of galactooligosaccharides delivered in ovo on mitigating negative effects of heat stress on performance and welfare of broilers. Poult Sci. (2020) 99:407-15. doi: 10.3382/ps/pez512

11. Lehninger AL, Nelson DL, Cox MM. Lehninger: Principles of Biochemistry. New York, NY: New York Academic Press (2005). procedures involved in the study, such as the rearing of experimental birds and sampling, were approved by the institute animal ethics committee and members of CPCSEA nominees. The IAEC approval number is CARI/CPCSEA/2017/07.

\section{AUTHOR CONTRIBUTIONS}

MG, JR, and AV: designed the experimental design and analyzed the collected data. PS and VMad: prepared the manuscript. VMan, MM, and MS: carried out the in ovo administration, biological experiment, and performed sample collection. BP and TT: carried out the laboratory analysis of biological samples. All authors read and approved the manuscript.

\section{ACKNOWLEDGMENTS}

We thank the Science and Engineering Research Board, Department of Science and Technology, Government of India, New Delhi for providing financial support to carry out the study (Sanction no. ECR/2016/001898).

12. Uauy R, Quan R, Gil A. Nucleotides in infant nutrition. In: Gil A, Uauy $\mathrm{R}$, editors. Nutritional and Biological Significance of Dietary Nucleotides and Nucleic Acids. Barcelona. (1996). p. 169-180.

13. Grimble GK, Westwood OM. Nucleotides. Nutrition and Immunology. New Jersey: Humana Press. (2000). p. 135-44.

14. Karasov WH, Douglas AE. Comparative digestive physiology. Comp Physiol (2013) 3:741-83. doi: 10.1002/cphy.c110054

15. Weström B, Arévalo Sureda E, Pierzynowska K, Pierzynowski SG, Pérez-Cano FJ. The immature gut barrier and its importance in establishing immunity in newborn mammals. Front Immunol. (2020) 11:1153. doi: 10.3389/fimmu.2020.01153

16. Bhanja SK, Mandal AB, Johari TS. Standardization of injection site, needle length, embryonic age and concentration of amino acids for in ovo injection in broiler breeder eggs. Indian J Poult Sci. (2004) 39:105-11.

17. Gopi M, Shyamkumar TS, Tyagi JS, Jaywant JR, Kolluri G, Khillare G. Dietary nucleosides improved performance and gut health lately in broilers. In: Proceedings of the XVth European Poultry Conference Dubrovnik, Croatia. (2018). p. 268.

18. ICAR (Indian Council of Agricultural Research). Nutrient Requirements of Poultry. New Delhi, India: Indian Council of Agricultural Research (2013).

19. Hill FW, Anderson DL. Comparison of metabolizable energy and productive energy determinations with growing chicks. J Nutr. (1958) 64:587603. doi: $10.1093 /$ jn/64.4.587

20. Pelícia VC, Sartori JR, Zavarize KC, Pezzato AC, Stradiotti AC, Araujo PC, et al. Effect of nucleotides on broiler performance and carcass yield Brazilian J Poult Sci. (2010) 12:31-4. doi: 10.1590/S1516-635X2010000 100004

21. Esteve-Garcia E, Martinez-Puig D, Borda E, and Chetrit C. Efficacy of a nucleotide preparation in broiler chickens. In: Proceedings of the 16th European Symposium on Poultry Nutrition. Strasbourg. (2007). p. 511-514.

22. Maribo H, Spring P. Yeast extract as a protein source for weaning piglets. In: Schubert R. Flachowsky G, Jahreis G, editors. Vitamine und Zusatzstoffe in der Ernährung von Mensch und Tier. Jena Thüringen. (2003). p. 433-7.

23. Jung B, Batal AB. Effect of dietary nucleotide supplementation on performance and development of the gastrointestinal tract of broilers. Br Poult Sci. (2012) 53:98-105. doi: 10.1080/00071668.2012.659654 
24. Yamauchi K, Adjei AA, Ameho CK, Sato S, Okamoto K, Kakinohana S, et al. Nucleoside-nucleotide mixture increases bone marrow cell number and small intestinal RNA content in protein deficient mice after an acute bacterial infection. Nutrition. (1998) 14:270. doi: 10.1016/s0899-9007(97) 00469-3

25. Garcia-Molina V, Anguilera JA, Gil A, Sanchezpozo A. Plasma lipoproteins in suckling rats: effect of dietary nucleotides. J Cl Nutr Gastroenter. (1991) 6:18490.

26. Buyse J, Jassens K, Van Der Geyten S, Van As P, Decuypere E, Darras VM. Pre- and postprandial changes in plasma hormone and metabolite levels and hepatic deiodinase activities in meal-fed broiler chickens. British, J Nutr. (2002) 88:641-53. doi: 10.1079/BJN2002741

27. Uauy R, Stringel G, Thomas R, Quan R. Effect of dietary nucleosides on growth and maturation of the developing gut in the rat. J Pediatric Gastroenterol Nutr. (1990) 10:497503. doi: 10.1097/00005176-199005000-00014

28. Bueno J, Torres M, Almendros A, Carmona R, Nunez MC, Rios A, et al. Effect of dietary nucleotides on small intestinal repair after diarrhoea. Histol Ultrastruct Changes Gut. (1994) 35:926-33. doi: 10.1136/gut.35.7.926

29. Bartell SM, Batal AB. The effect of supplemental glutamine on growth performance, development of the gastrointestinal tract, and humoral immune response of broilers. Poult Sci. (2017) 86:1940-7. doi: 10.1093/ps/86.9.1940

30. Carver JD. Dietary nucleotides: effects on the immune and gastrointestinal systems. Acta Paediatrica. (1999) 88:83-8.
31. Izat AL, Colberg M, Adams MH, Reiber MA, Waldroup PW. Production and processing studies to reduce the incidence of Salmonellae on commercial broilers. J Food Protect. (1989) 52:670-3. doi: 10.4315/0362-028x-52. 9.670

32. Martinez-Puig D, Manzanilla EG, Morales J, Borda E, Pérez JF, Piñeiro C, et al. Dietary nucleotide supplementation reduces occurrence of diarrhoea in early weaned pigs. Liv Sci. (2007) 108:276-9. doi: 10.1016/j.livsci.2007. 01.099

33. Hess JR, Greenberg NA. The role of nucleotides in the immune and gastrointestinal systems: potential clinical applications. Nutr Cl Practice. (2012) 27:281-94. doi: 10.1177/0884533611434933

Conflict of Interest: The authors declare that the research was conducted in the absence of any commercial or financial relationships that could be construed as a potential conflict of interest.

Copyright (c) 2020 Gopi, Manojkumar, Verma, Singh, Rokade, Pearlin, Monika, Madhupriya, SaravanaKumar and Tamilmani. This is an open-access article distributed under the terms of the Creative Commons Attribution License (CC BY). The use, distribution or reproduction in other forums is permitted, provided the original author(s) and the copyright owner(s) are credited and that the original publication in this journal is cited, in accordance with accepted academic practice. No use, distribution or reproduction is permitted which does not comply with these terms. 